Open Access

\title{
Prokaryotic expression and mechanism of action of a-helical antimicrobial peptide A20L using fusion tags
}

Tonghui $Y^{1,3}$, Shiyu Sun ${ }^{1,3}$, Yibing Huang ${ }^{1,2,3}$ and Yuxin Chen ${ }^{1,2,3^{*}}$

\begin{abstract}
Background: Antimicrobial peptides have become important candidates as new antibiotics against resistant bacterial strains. However, the major industrial manufacture of antimicrobial peptides is chemical synthesis with high costs and in relatively small scale. The Ub-tag and SUMO-tag are useful for increasing the yield of enzymes and other proteins in expression system. In this study, antimicrobial peptide A20L (KWKSFLKTFKSAKKTVLHTLLKAISS), a derivative of V13K in the previous study is used as a template to be expressed in different Ub-tag and human SUMO tag systems to compare the prokaryotic expression approaches of antimicrobial peptide. The antibacterial mechanism of action and membrane specificity of A2OL was further studied.

Methods: We fused the Ub and SUMO1/2/3/4 with A2OL to construct expression plasmids. Ub-A2OL and SUMO1/2/34 gene sequences were inserted into the pHUE plasmids and pET-28b+ plasmids, respectively, to construct pHUE-A2OL plasmids and pET-28b+-SUMO1/2/3/4-A2OL plasmids. These plasmids were transformed into E. coli Rosetta (DE3) and induced with IPTG to express Ub-A2OL and SUMO1/2/3/4 fusion proteins. The recombinant proteins were found in the soluble fraction after being over expressed in E. coli Rosetta (DE3). Antibacterial and hemolytic activities and membrane permeabilization ability of A2OL were determined. Peptide structure was also studied by circular dichroism experiments.

Results: A20L (KWKSFLKTFKSAKKTVLHTLLKAISS) was successfully expressed by fusion with an ubiquitin tag (Ub-tag) and human SUMO tags (SUMO1/2/3/4-tags). A2OL exhibited antimicrobial activity against various Gram-negative and Gram-positive bacteria. Based on the hemolytic activity against human red blood cells, A20L showed good specificity against bacteria. The circular dichroism experiments illustrated that A20L was transferred into an a-helical structure in the presence of hydrophobic environment. The antibacterial mechanism of action and membrane specificity of A20L was further studied using membrane permeabilization experiments and tryptophan fluorescence and quenching experiments in liposomes.
\end{abstract}

Conclusions: The Ub-tag and human SUMO-tags represent good alternatives to chemical synthesis for the industrial production of antimicrobial peptides with low costs and high yields. The antibacterial mechanism of action of A20L was proved as membrane disruption. A20L showed stronger specificity on liposomes mimicking bacterial membrane than those mimicking eukaryotic cell membrane, which is consistent with the biological activity studies.

Keywords: Antimicrobial peptide, Ubiquitin, Small ubiquitin-related modifier, Liposome, Specificity

\footnotetext{
* Correspondence: chen_yuxin@jlu.edu.cn

${ }^{1}$ Key Laboratory for Molecular Enzymology and Engineering of the Ministry

of Education, Jilin University, 2699 Qianjin St., Changchun, Jilin 130012, P. R.

China

${ }^{2}$ National Engineering Laboratory for AIDS Vaccine, Jilin University,

Changchun, China

Full list of author information is available at the end of the article
}

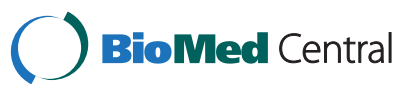

(C) 2015 Yi et al. This is an Open Access article distributed under the terms of the Creative Commons Attribution License (http://creativecommons.org/licenses/by/4.0), which permits unrestricted use, distribution, and reproduction in any medium, provided the original work is properly credited. The Creative Commons Public Domain Dedication waiver (http:// creativecommons.org/publicdomain/zero/1.0/) applies to the data made available in this article, unless otherwise stated. 


\section{Background}

Bacteria are developing resistance to antibiotics at an alarming rate, thus the development of new antibiotic alternatives continues to be extremely urgent $[1,2]$. Because of their antibacterial properties, antimicrobial peptides (AMPs) are expected to become ideal antibiotic alternatives [3]. AMPs are generally between 10 and 50 amino acid residues, and are strongly cationic (pI 8.9-10.7) [4]. AMPs are characterized by their broad spectrum of activities and their antibacterial mechanism differs from traditional antibiotics [5]. To date, there are more than 2000 types of AMPs that have been isolated, including some that have been used in the health care and food processing industries [6, 7].

AMPs are primarily harvested via natural extraction, chemical synthesis and genetic engineering. The largescale application of AMPs is restricted by limitations in sourcing the natural products and the high production costs of chemical synthesis. A prokaryotic expression system can reduce the production cost of AMPs and increase their large-scale applications [8]. However, prokaryotic expression of AMPs is technically challenging because AMPs are not only toxic to the host, but also susceptible to exogenous protease degradation. Previous studies have shown that use of a fusion tag system can achieve effective expression of AMPs [9]. Fusion tags commonly used include thioredoxin, steroid isomerase and glutathione-S-transferase enzymes. However new fusion tags useful to improve the yield of AMPs are continuously coming out.

Ubiquitin (Ub) has 76 amino acids and mainly functions to label proteins for hydrolysis [10]. Small ubiquitin-related modifier (SUMO) consists of about 100 amino acid residues, and modulates protein structure and function by covalent modification of target proteins in eukaryotes. Yeast cells have only one SUMO gene (SMT3), while there are four SUMO genes in vertebrates, SUMO1, SUMO2, SUMO3, SUMO4 [11]. Recent studies have shown that Ub and SUMO were used as fusion tags. Their small sizes bring relatively high peptide-to-carrier ratios, favors the increase of yield in the production of antimicrobial peptides. The highly specific sumoase facilitates efficient release of the antimicrobial peptide [12]. In previous studies, we obtained the AMP A20L (KWKSFLKTFKSAKKTVLHTLLKAISS, 2991.6 Da) [13], which is a derivative of the V13K in which the amino acid alanine in position 20 was substituted by leucine, and showed that it possesses good antimicrobial activity and low hemolytic activity. In this study, we used the Ub-tag and human SUMO1/2/3/4-tag fusion to express A20L in a prokaryotic system and further explore the antibacterial mechanism of action of AMPs with membrane permeabilization experiments, tryptophan fluorescence and quenching experiments in liposomes.

\section{Methods}

\section{Materials}

Escherichia coli (E. coli) strain DH5 $\alpha$, Rosetta (DE3) and the expression plasmid pET-28b + were purchased from Novagen Co. Ltd. (Darmstadt, Germany). Sumoase and pHUE were gifts from Prof. Xuexun Fang, Jilin University, China. The plasmid pHUE was constructed for the expression of His-tagged ubiquitin (Ub) fusion proteins by modifying pET15b. It contains the inducible T7 RNA polymerase promoter, a histidine tag at the $5^{\prime}$ end of an ubiquitin open reading frame and an extended polylinker [14]. pUC57-SUMO1/2/3/4-A20L and pUC57-A20L plasmids were constructed by Genewiz Co. Ltd. (Suzhou, China). E. coli ATCC25922, Pseudomonas aeruginosa (P. aeruginosa) ATCC27853, Staphylococcus aureus (S. aureus) ATCC25923, Bacillus subtilis (B. subtilis) ATCC6633 and E. coli ML-35 ATCC 43827 were purchased from the American Type Culture Collection (USA). Restriction endonucleases NdeI, BamHI and EcoRI were purchased from Takara Biotech Co. Ltd. (Dalian, China). The bicinchoninic acid (BCA) protein assay kit was purchased from Shanghai Biological Engineering Co., Ltd., China. Luria-Bertani (LB) medium and MuellerHinton $(\mathrm{MH})$ medium were purchased from Dingguo Co. Ltd. (Beijing, China). CM Sepharose FF chromatography medium was purchased from GE Chemical Co. (Uppsala,USA), and Ni-NTA chromatography medium was purchased from Qiagen Co. Ltd. (Hilden, Germany). Prestained SDS-PAGE standards were purchased from Transgen Co. Ltd. (Beijing, China). Trifluoroethanol (TFE), 1-N-phenylnaphthylamine (NPN), o-nitrophenyl- $\beta$ D-galactoside (ONPG) and phenylmethanesulfonyl fluoride (PMSF) were purchased from Sigma (Beijing, China). L- $\alpha$-phosphatidyl-dl-glycerol (PG), L- $\alpha$-phosphatidylcholine (PC) and cholesterol were purchased from Avanti Polar Lipids, Inc. (Alabama, USA). HEPES and KI were purchased from Beijing Chemical Works (Beijing, China).

\section{Plasmid construction}

The pUC57-SUMO1/2/3/4-A20L and pUC57-A20L plasmids were served as templates. The A20L gene sequence (AAATGGAAATCTTTCCTGAAAACCTTCAAATCTG CTAAAAAAACCGTTCTGCACACCCTGCTGAAAGC TATCTCTTCT) was amplified by PCR (Additional file 1: Table S1 and Table S2). The PCR product of the A20L and pHUE plasmid was doubly digested by BamHI and EcoRI. The PCR products of SUMO1/2/3/4-A20L and the pET-28b + plasmid were doubly digested with $N d e I$ and EcoRI. After digestion, T4 DNA Ligase was used to link and transform E. coli $\mathrm{DH} 5 \alpha$ competent cells, and then monoclonal colonies were inoculated in LB culture medium for plasmid sequencing. The plasmid construction process is shown in Fig. 1. 


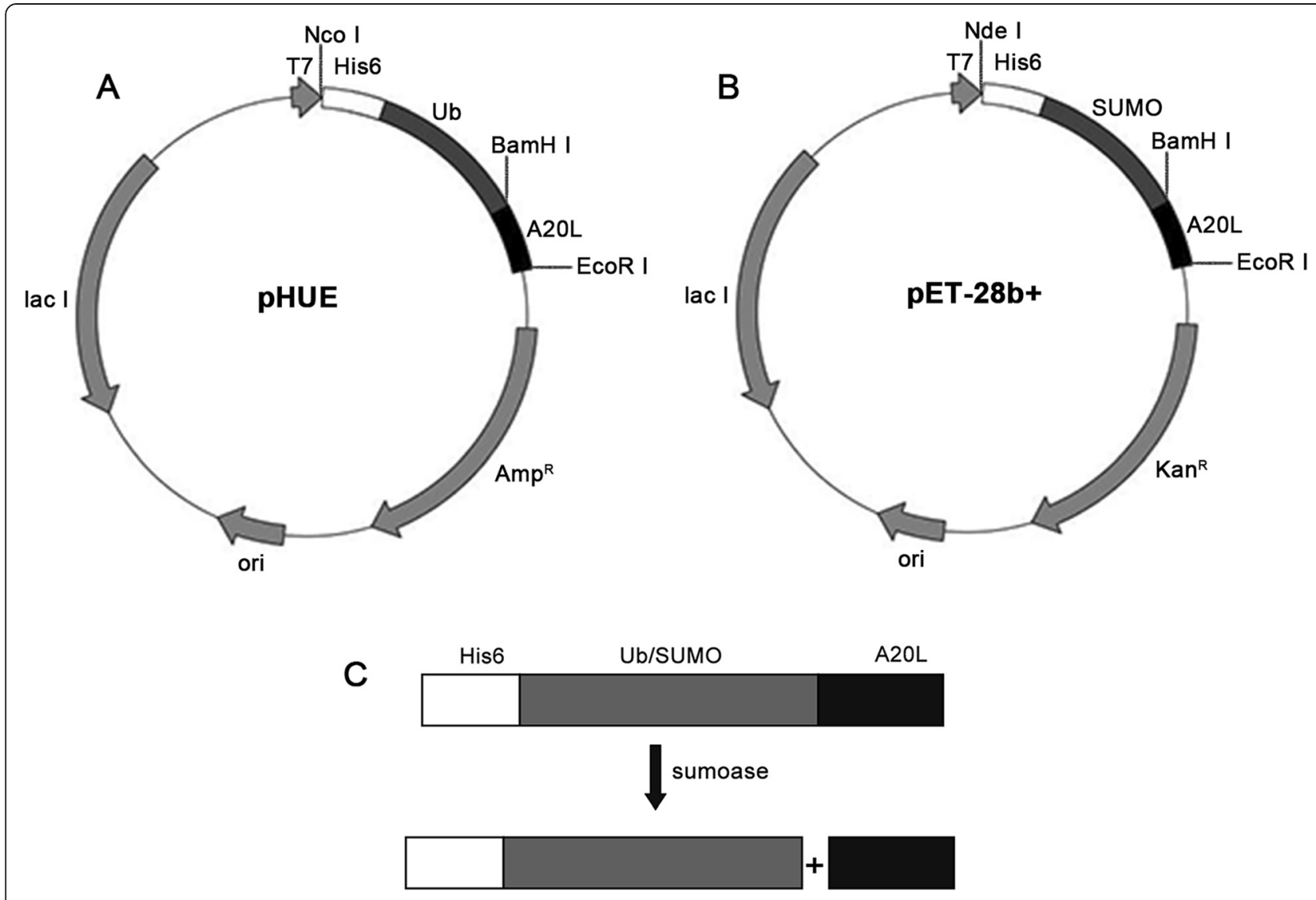

Fig. 1 The cloning and cleavage strategy for Ub-A2OL and SUMO1/2/3/4-A20L. (a) pHUE-A20L, which was constructed by inserting the A20L gene at the BamHI/EcoRl sites of pHUE; (b) pET28b + -SUMO1/2/3/4-A20L, which was constructed by inserting the A2OL gene at the BamHI/EcoRl sites of pET-28b+; (c) the cleavage strategy for Ub-A2OL and SUMO-A2OL

Fusion protein expression, purification and digestion The pET-28b + -SUMO1/2/3/4-A20L and pHUE-A20L plasmids were transformed into $E$. coli Rosetta (DE3) competent cells. Single colonies were picked, shaken and cultured at $37{ }^{\circ} \mathrm{C}$ and $180 \mathrm{rpm}$ for $16 \mathrm{~h}$. Then, the bacterial suspension at a volume ratio of 1:100 was cultured in $\mathrm{LB}$ medium, shaken at $37^{\circ} \mathrm{C}, 180 \mathrm{rpm}$ for $3 \mathrm{~h}$ until the $\mathrm{OD}_{600} \mathrm{~nm}$ was $0.4-0.6$. Isopropyl $\beta$-D-1-thiogalactopyranoside (IPTG) at a final concentration of $1 \mathrm{mM}$ was added to induce expression at $32{ }^{\circ} \mathrm{C}$ and $180 \mathrm{rpm}$ for $4 \mathrm{~h}$ followed by centrifugation $(6000 \times \mathrm{g}$ for $10 \mathrm{~min})$. After addition of Buffer A $\left(50 \mathrm{mM} \mathrm{Na} 2 \mathrm{HPO}_{4} / \mathrm{NaH}_{2} \mathrm{PO}_{4}\right.$, $300 \mathrm{mM} \mathrm{NaCl}, 1 \mathrm{mM}$ phenylmethanesulfonyl fluoride, $\mathrm{pH} 7.4)$, the samples were sonicated (200 W, $10 \mathrm{~min})$ and centrifuged to collect the supernatant. A $2 \mathrm{~mL} \mathrm{Ni-}$ NTA column was washed and equilibrated with Buffer B (50 mM Na $\mathrm{HPO}_{4} / \mathrm{NaH}_{2} \mathrm{PO}_{4}, 300 \mathrm{mM} \mathrm{NaCl}, \mathrm{pH}$ 7.4) and then the supernatant was cycled over the $\mathrm{Ni}$ NTA column for $1 \mathrm{~h}$. After rinsing with Buffer $\mathrm{B}$ and $10 \mathrm{~mL}$ Buffer C (50 mM Na $2 \mathrm{HPO}_{4} / \mathrm{NaH}_{2} \mathrm{PO}_{4}, 300 \mathrm{mM}$ $\mathrm{NaCl}, 50 \mathrm{mM}$ imidazole, $\mathrm{pH}$ 7.4), $10 \mathrm{~mL}$ Buffer D (50 mM Na $\mathrm{HPO}_{4} / \mathrm{NaH}_{2} \mathrm{PO}_{4}, 300 \mathrm{mM} \mathrm{NaCl}, 300 \mathrm{mM}$ imidazole, $\mathrm{pH}$ 7.4) was used to elute the target proteins, Ub-A20L and SUMO1/2/3/4-A20L. Target proteins were dialyzed against $500 \mathrm{~mL}$ Buffer E $(20 \mathrm{mM}$ $\mathrm{Na}_{2} \mathrm{HPO}_{4} / \mathrm{NaH}_{2} \mathrm{PO}_{4}, \mathrm{pH}$ 8.4) overnight. A $10 \mathrm{~mL} \mathrm{CM}$ Sepharose FF column was first equilibrated with Buffer $\mathrm{E}$, and loaded with the target proteins for $1 \mathrm{~h}$, followed by purification with Buffer $\mathrm{F}(20 \mathrm{mM}$ $\mathrm{Na}_{2} \mathrm{HPO}_{4} / \mathrm{NaH}_{2} \mathrm{PO}_{4}, 0.1-1 \mathrm{M} \mathrm{NaCl}, \mathrm{pH} 8.4$ ) to yield Ub-A20L and SUMO1/2/3/4-A20L. The purity of the target proteins was assessed using $12 \%$ SDS-PAGE electrophoresis. The fused proteins were combined with sumoase at a molar ratio of 1:50 and digested overnight at $4{ }^{\circ} \mathrm{C}$. After digestion, a Sephadex G25 column $(2 \mathrm{~cm} \times 80 \mathrm{~cm})$ was employed for separation purpose. Buffer G $\left(20 \mathrm{mM} \quad \mathrm{Na}_{2} \mathrm{HPO}_{4} / \mathrm{NaH}_{2} \mathrm{PO}_{4}\right.$, $\mathrm{pH}$ 7.4) was used as an eluent to purify A20L. Tricine SDS-PAGE electrophoresis analysis was used to check the purity of A20L, and the polypeptide yield was determined using the Walker method [15]. The concentrations of A20L were calculated in the equation: A20L (in $\mu \mathrm{g} / \mathrm{ml})=144 \times\left(\mathrm{OD}_{215 \mathrm{~nm}^{-}} \mathrm{OD}_{225 \mathrm{~nm}}\right)$. The experiments were separately performed six times. 


\section{Antibacterial activity determination}

The minimal inhibitory concentration (MIC) of A20L was determined using the broth dilution method [16]. A single bacterial colony was picked and cultured at $37{ }^{\circ} \mathrm{C}, 180 \mathrm{rpm}$ for overnight. Wells of a 96-well plates were filled with $90 \mu \mathrm{L}$ of the bacterial suspension $\left(5 \times 10^{5} \mathrm{CFU} / \mathrm{mL}\right.$ in $\mathrm{MH}$ media) and $10 \mu \mathrm{L}$ of of serial two fold dilutions of the A20L peptide (stock concentration $2 \mathrm{mg} / \mathrm{mL}$ ) and cultured at $37{ }^{\circ} \mathrm{C}$ and $170 \mathrm{rpm}$, for $24 \mathrm{~h}$. The $\mathrm{OD}_{590 \mathrm{~nm}}$ was determined to calculate the MIC. The experiments were performed in triplicates.

\section{Hemolytic activity determination}

The A20L peptides were doubly diluted at an initial concentration of $2 \mathrm{mg} / \mathrm{mL}$ and added to 96-well plates at a density of $70 \mu \mathrm{L}$ per well. Healthy human blood $(1-2 \mathrm{~mL})$ from healthy volunteers was centrifuged at $1000 \times \mathrm{g}$ for $5 \mathrm{~min}$ and washed thrice with PBS. Erythrocytes were resuspended and counted, and diluted to a concentration of $2 \times 10^{8}$ cells $/ \mathrm{mL}$. The diluted erythrocytes were added to 96-well plates at a density of $70 \mu \mathrm{L}$ per well and mixed with A20L, incubated at $37^{\circ} \mathrm{C}$ for $2 \mathrm{~h}$, and centrifuged at $3000 \times$ $\mathrm{g}$ for $10 \mathrm{~min}$. The release of hemoglobin was determined by measuring the optical density of the supernatant at $\mathrm{OD}_{578 \mathrm{~nm}}$. The hemolytic activity was measured as the minimal hemolytic concentration (MHC). PBS containing $1 \%$ erythrocytes and distilled water were used as a negative control and $100 \%$ hemolysis positive control [16], respectively. The experiments were performed in triplicates.

\section{Circular dichroism experiments}

The secondary structures of the A20L peptide at a concentration of $75 \mu \mathrm{M}$ were determined using a Jasco J-810 circular dichroism spectrometer (Jasco, Easton, MD) at $25{ }^{\circ} \mathrm{C}$ in non-denaturating buffer $(100 \mathrm{mM} \mathrm{KCl}, 50 \mathrm{mM}$ $\mathrm{KH}_{2} \mathrm{PO}_{4} / \mathrm{K}_{2} \mathrm{HPO}_{4}, \mathrm{pH} 7.0$ ) or in the presence of $\alpha$-helix inducing $50 \%$ 2,2,2-trifluoroethanol (TFE) (non-denaturating buffer:TFE $=1: 1, \mathrm{vol} / \mathrm{vol}$ ). The A20L secondary structure was confirmed by calculating the average molar ellipticity at $222 \mathrm{~nm}\left([\theta]_{222}\right)$ [17]. The experiments were separately performed three times.

\section{Outer membrane permeabilization experiments}

The change of outer membrane permeability in bacteria after interaction with A20L was analyzed using the hydrophobic fluorescent probe 1-N-phenylnaphthylamine (NPN). P. aeruginosa was inoculated in $20 \mathrm{~mL} \mathrm{LB}$ liquid medium, shaken and cultured at $37{ }^{\circ} \mathrm{C}$ for $18 \mathrm{~h}$. A $1 \mathrm{~mL}$ bacterial suspension was inoculated into $50 \mathrm{~mL}$ of $\mathrm{LB}$ medium, shaken and cultured at $37{ }^{\circ} \mathrm{C}$ until the $\mathrm{OD}_{600 \mathrm{~nm}}$ was $0.4-0.6$. After centrifugation $(4000 \times \mathrm{g}$ for $10 \mathrm{~min})$, bacteria were collected and resuspended in buffer $(5 \mathrm{mM}$ HEPES, $5 \mathrm{mM} \mathrm{NaN}_{3}, 0.25 \mathrm{mM} \mathrm{NPN}, \mathrm{pH}$ 7.4) to $\mathrm{OD}_{600}$ $\mathrm{nm}=0.5$ which equated to $300 \mu \mathrm{L}$ of a $800 \mu \mathrm{g} / \mathrm{mL}$ A20L solution added to $2.7 \mathrm{~mL}$ of bacterial suspension. A negative control was prepared in the same volume of reaction buffer ( $5 \mathrm{mM}$ HEPES, $5 \mathrm{mM} \mathrm{NaN}_{3}, \mathrm{pH}$ 7.4). A Shimadzu RF-5301 PC spectrofluorophotometer (excitation wavelength $350 \mathrm{~nm}$, emission wavelength $420 \mathrm{~nm}$ ) was used to continuously collect data for $10 \mathrm{~min}$ [18]. The experiments were separately performed ten times.

\section{Inner membrane permeabilization experiments}

Permeabilization of the inner membrane was assessed by measuring the access of o-nitrophenyl $\beta$-D-galactopyranoside (ONPG) to the cytoplasm. We used the permease-deficient strain E. coli $M L-35$, which constitutively expresses cytoplasmic $\beta$-galactosidase. E. coli $M L-35$ was cultured in LB medium containing $5 \%$ lactose. The bacterial cells were collected and resuspended with sterile water to an $\mathrm{OD}_{420 \mathrm{~nm}}$ of 1.2. A total of $1000 \mu \mathrm{L}$ of bacterial suspension was mixed with $100 \mu \mathrm{L}$ of $30 \mathrm{mM}$ onitrophenyl- $\beta$-D-galactosidase (ONPG), and then added to $900 \mu \mathrm{L}$ of $16 \mu \mathrm{g} / \mathrm{mL}$ A20L. The negative control was carried out with $0.5 \% \mathrm{NaCl}$. A Shimadzu UV-2550 UV spectrophotometer (wavelength set to $420 \mathrm{~nm}$ ) was used to continuously collect data for $90 \mathrm{~min}$ [19].

\section{Tryptophan fluorescence and quenching experiments}

As reported previously, the liposomes were prepared and cultured in HEPES buffer (pH 7.4, 10 mM HEPES, $150 \mathrm{mM} \mathrm{NaCl}$ ) such that their molar concentration was adjusted to $100 \mu \mathrm{M}$ [20]. A total of $14 \mu \mathrm{L}$ of $100 \mu \mathrm{M}$ A20L and $686 \mu \mathrm{L}$ of $100 \mu \mathrm{M}$ liposomes were combined together at $25{ }^{\circ} \mathrm{C}$ for $10 \mathrm{~min}$. A Shimadzu RF-5301 PC, (excitation wavelength: $350 \mathrm{~nm}$, emission wavelength of 300-450 nm) was used to measure the tryptophan fluorescence [20]. Potassium iodide (KI) at a final concentration of 0.02-0.08 M was added to the reaction system and the tryptophan fluorescence was measured as described above. The SternVolmer equation was used to calculate the quenching constant $\mathrm{K}_{\mathrm{sv}}$. The experiments were performed in triplicates.

\section{Ethics and consent statements}

Research involving human subjects that is reported in the manuscript has been performed with the approval of the ethics committee of School of Life Sciences, Jilin University, China (Reference No. JSK-RTLL2014003). Research carried out on humans is in compliance with the Helsinki Declaration. The written informed consent for the participant who supplies human red blood cells in this study was obtained from the participant.

\section{Results}

Expression, purification and digestion of $\mathrm{Ub}-\mathrm{A} 2 \mathrm{OL}$ and SUM01/2/3/4-A20L

To explore the function of Ub protein and SUMO1/2/3/ 4 proteins as fusion tags, we fused the Ub and SUMO1/ 2/3/4 with A20L to construct expression plasmids. Ub- 


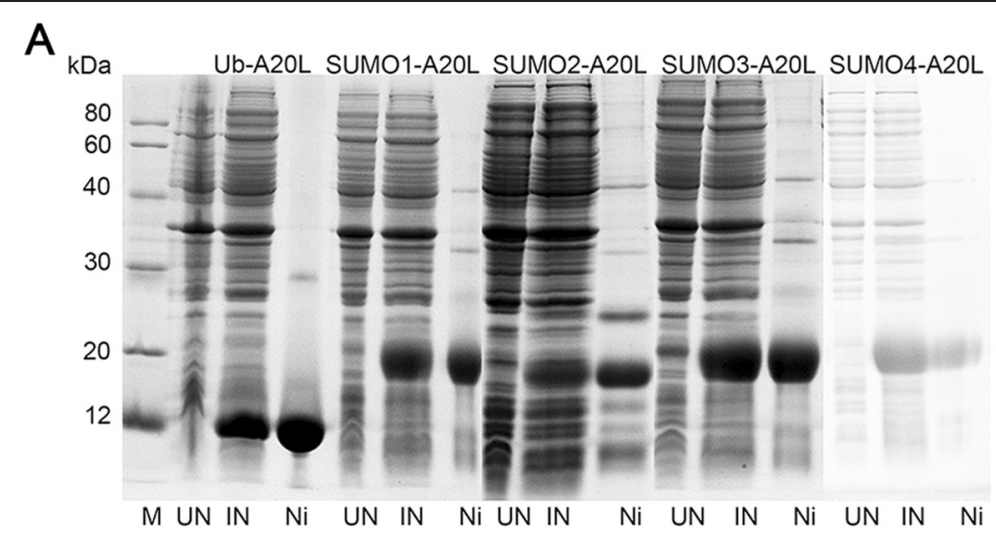

B

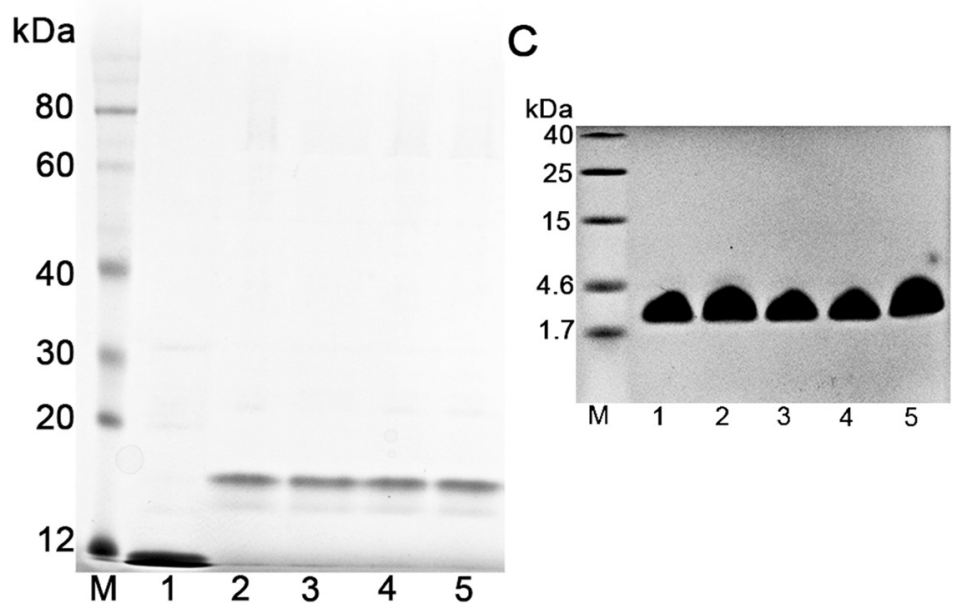

Fig. 2 (a) Expression of A2OL fused with Ub, SUMO1, SUMO2, SUMO3 and SUMO4 proteins. (M): molecular weight marker; (UN): un-induced culture; (IN): induced culture; (Ni): Ni-NTA purified pool; (b) purification of Ub-A20Land SUMO1/2/3/4-A20L by CM Sepharose FF. (M): molecular weight marker; (1) Ub-A20L; (2) SUMO1-A2OL; (3) SUMO2-A20L; (4) SUMO3-A20L; (5) SUMO4-A2OL; (c) purification of A20L (M): molecular weight marker; (1-5): A20L purified from Ub-A20L(1),SUMO1-A20L(2),SUMO2-A2OL(3), SUMO3-A20L(4),SUMO4-A20L(5)

A20L and SUMO1/2/34 gene sequences were inserted into the pHUE plasmids and pET-28b + plasmids, respectively, to construct pHUE-A20L plasmids and pET$28 \mathrm{~b}+-\mathrm{SUMO} 1 / 2 / 3 / 4-\mathrm{A} 20 \mathrm{~L}$ plasmids. These plasmids were transformed into E. coli Rosetta (DE3) and induced with IPTG to express Ub-A20L and SUMO1/2/3/4 fusion proteins. The recombinant proteins were found in the soluble fraction after being over expressed in E. coli Rosetta (DE3). Their relative expression levels were calculated by gel scanning (Fig. 2a and b). The yield of the protein expression was $76.3 \mathrm{mg} / \mathrm{L}$ and $51.5-21.9 \mathrm{mg} / \mathrm{L}$ for $\mathrm{Ub}-$ A20L and SUMO1/2/3/4, respectively (Fig. 2a; Table 1). After cell disruption, the supernatant was obtained and purified using Ni-NTA affinity chromatography and CM Sepharose FF cation exchange chromatography. The peptide purity was determined by $12 \%$ SDS-PAGE, and the protein yield was determined by the BCA method. The yield of Ub-A20L and SUMO1/2/3/4-A20L was

Table 1 Purification of A2OL from E. coli Rosetta (DE3) cells expressing Ub-A2OL and SUMO1/2/3/4-A20L in a batch culture of $1 \mathrm{~L}$

\begin{tabular}{|c|c|c|c|c|}
\hline Protein & Target protein after $1 \mathrm{mM}$ IPTG induction $(\mathrm{mg})^{a}$ & Ni-NTA pool $(\mathrm{mg})^{\mathrm{b}}$ & CM Sepharose FF pool $(\mathrm{mg})^{\mathrm{b}}$ & $\mathrm{A} 20 \mathrm{~L}(\mathrm{mg})^{\mathrm{c}}$ \\
\hline $\mathrm{His}_{6}-\mathrm{Ub}-\mathrm{A} 2 \mathrm{OL}$ & 76.3 & 51.2 & 46.5 & 7.3 \\
\hline $\mathrm{His}_{6}-\mathrm{SUMO1}-\mathrm{A} 2 \mathrm{OL}$ & 52.0 & 33.8 & 30.6 & 5.4 \\
\hline $\mathrm{His}_{6}-\mathrm{SUMO} 2-\mathrm{A} 2 \mathrm{OL}$ & 48.7 & 29.7 & 24.1 & 3.2 \\
\hline $\mathrm{His}_{6}-\mathrm{SUMO}-\mathrm{A} 2 \mathrm{OL}$ & 61.5 & 36.4 & 32.9 & 4.8 \\
\hline $\mathrm{His}_{6}-\mathrm{SUMO} 4-\mathrm{A} 2 \mathrm{OL}$ & 21.9 & 13.6 & 10.2 & 2.0 \\
\hline
\end{tabular}

${ }^{a}$ The quantity of target protein was estimated by SDS gel scanning

${ }^{\mathrm{b}}$ The quantity of target protein was determined by the BCA method

'The quantity of $\mathrm{A} 2 \mathrm{LL}$ was determined by the Walker method [15] 
$51.2 \mathrm{mg} / \mathrm{L}$ and 13.6-36.4 mg/L, respectively (Fig. 2a, b; Table 1). After sumoase cleavage, the A20L peptide was obtained from Sephadex G25 column purification. The yield of the A20L peptide was $7.3 \mathrm{mg} / \mathrm{L}$ from Ub-A20L and 2.0$5.4 \mathrm{mg} / \mathrm{L}$ from SUMO1/2/3/4-A20L after enzyme digestion (Fig. 2c and Table 1). This indicates that both $\mathrm{Ub}$ and SUMO1/2/3/4 tags are able to promote the expression of the A20L peptide, but Ub-tag was effective than SUMO1/2/3/4.

\section{Antibacterial and hemolytic activities}

The geometric mean (GM) of the MIC values for the four microbial strains was calculated as an overall indicator of the antibacterial activity of the AMP. A20L exhibited strong antimicrobial activity against various Gram-negative and Gram-positive bacteria. The MIC values for Gram-negative and Gram-positive bacteria were $2.67-21.33 \mu \mathrm{g} / \mathrm{mL}$, and the GM value was calculated to be $6.87 \mu \mathrm{g} / \mathrm{mL}$, (Table 2). The MHC value of the peptide against human erythrocytes was determined to represent peptide toxicity. A20L showed negligible hemolytic activity against human red blood cells $(213.33 \mu \mathrm{g} / \mathrm{mL})$. The therapeutic index (TI) is a widely used parameter indicating the specificity of AMPs, and is expressed as the ratio of $\mathrm{MHC} / \mathrm{MIC}$. In this study, the TI was 31.05, indicating that the A20L peptide has high antibacterial specificity (Table 2).

\section{Peptide secondary structure}

The helicity is a biophysical parameter closely related to the antibacterial activity [20]. In this study, we studied the variation in the secondary structure of the A20L peptide by measuring its circular dichroism spectrum under different buffer systems. The results showed that the $[\theta]_{222}$ of A20L in the non-denaturating buffer was -4363 degree - $\mathrm{cm}^{2} \cdot \mathrm{dmol}^{-1}$, indicating that the structure of A20L is disordered, while the $[\theta]_{222}$ of the peptide was -33424 degree $\cdot \mathrm{cm}^{2} \cdot \mathrm{dmol}^{-1}$ in the presence of $50 \%$ TFE to mimic the hydrophobic environment, indicating that the peptide formed a typical $\alpha$-helical structure under hydrophobic environments such as biomembranes (Fig. 3).

\section{Membrane permeabilization}

Gram-negative bacterial cell membranes are divided into outer and inner membranes, whilst, Gram-positive bacteria only have cytoplasmic membranes, which are composed of similar lipid components as the inner membranes of Gram-negative bacteria. Pseudomonas aeruginosa and Escherichia coli ML-35 were selected for the outer membrane and inner membrane assays, respectively, since Pseudomonas aeruginosa is a most common infectious bacterium in clinics and Escherichia coli $M L-35$ is a lactose permease-deficient strain. AMPs provoke the disruption of the bacterial membrane to kill the bacteria. After A20L interacts with bacteria, changes in the outer membrane permeability can be detected using the fluorescence probe NPN. The fluorescence intensity emitted from NPN is weak in a hydrophilic environment, but very strong in a hydrophobic environment such as the hydrophobic core of a bacterial cell membrane [18]. In the outer membrane permeabilization experiment, after the interaction of A20L with bacteria, NPN was deeply inserted into the core of hydrophobic region within $2 \mathrm{~min}$, and the fluorescence intensity was observed to increase from 50 to 650 (Fig. 4a).

$\beta$-Galactosidase is located in the bacterial cytoplasm, and can hydrolyze ONPG into galactose and $o$-nitrophenol which shows yellow color. In untreated E. coli, ONPG is transferred into the cytoplasm via lactose permease, while if inner membrane destruction has occurred, ONPG can rapidly enter into the bacteria to react with $\beta$ galactosidase. By measuring the change in $\mathrm{OD}_{420 \mathrm{~nm}}$, we could determine whether or not ONPG was able to penetrate the cytoplasm, thus indicating whether the bacterial inner membrane is damaged [19]. The intracellular release of $\beta$-galactosidase became stable after $10 \mathrm{~min}$ and the $\mathrm{OD}_{420 \mathrm{~nm}}$ increased from 0.6 to 1.4 (Fig. 4b). Outer and inner membrane permeabilization assays indicate that the A20L peptide exhibited destructive effects on both bacteria membranes. Additionally, there was a clear distinction between the penetration time of A20L into the outer and inner bacterial membranes. As expected, A20L first damaged the outer membranes, then the inner membranes were also damaged subsequently.

\section{Interaction of A20L with liposomes}

In this study, tryptophan fluorescence and quenching experiments were carried out to study the insertion of A20L into different types of membrane structures. Tryptophan fluorescence Intensity is increased in a hydrophobic environment, and the blue shift occurred at the

Table 2 Antimicrobial (MIC) and hemolytic (MHC) activities of A2OL

\begin{tabular}{|c|c|c|c|c|c|c|c|}
\hline \multirow[t]{4}{*}{ Peptide } & \multicolumn{5}{|l|}{ MIC } & \multirow{4}{*}{$\begin{array}{l}\mathrm{MHC} \\
(\mu \mathrm{g} / \mathrm{ml})\end{array}$} & \multirow[t]{4}{*}{$\mathrm{Tl}^{\mathrm{b}}$} \\
\hline & \multicolumn{5}{|l|}{$(\mu \mathrm{g} / \mathrm{ml})$} & & \\
\hline & Escherichia Coli & Pseudomonas aeruginosa & Staphylococcus aureus & Bacillus subtilis & $G M^{a}$ & & \\
\hline & ATCC25922 & ATCC27853 & ATCC25923 & ATCC6633 & & & \\
\hline A20L & 2.67 & 7.33 & 21.33 & 5.33 & 6.87 & 213.33 & 31.05 \\
\hline
\end{tabular}




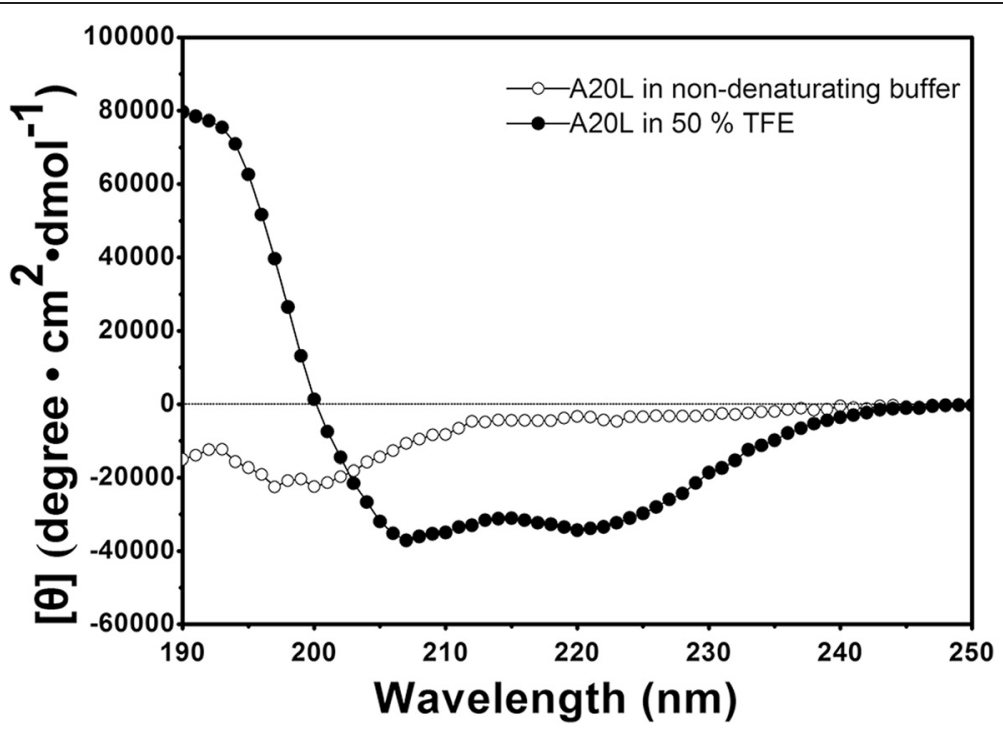

Fig. 3 Circulat dichroism (CD) spectra of the antimicrobial peptide A20L. Open symbols denote the CD spectra of the peptide in non-denaturating conditions ( $\mathrm{KP}$ buffer: $\mathrm{pH} 7,50 \mathrm{mM} \mathrm{KH} \mathrm{PO}_{4} / \mathrm{K}_{2} \mathrm{HPO}_{4}, 100 \mathrm{mM} \mathrm{KCl}$ ); solid symbols denote the CD spectra obtained in the presence of an a-helix inducing solvent TFE (KP buffer: TFE $=1: 1, \mathrm{vol} / \mathrm{VO}$ )

maximum emission wavelength. In the absence of the peptide, the maximum emission wavelength of tryptophan fluorescence was $346.7 \mathrm{~nm}$. The liposomes PC/PG $(7: 3, \mathrm{w} / \mathrm{w})$ and the $\mathrm{PC} /$ cholesterol $(8: 1, \mathrm{w} / \mathrm{w})$ were made to mimic a bacterial and a eukaryotic membrane, respectively [21]. When the A20L interacted with the $\mathrm{PC} /$ cholesterol liposomes, the maximum emission wavelength was $341.3 \mathrm{~nm}$, with no obvious blue shift, which indicates that the A20L peptide did not strongly interact with the eukaryotic cell membrane. By contrast, when the A20L interacted with the PC/PG liposomes, the maximum emission wavelength of tryptophan fluorescence was $315.7 \mathrm{~nm}$ was accomplished by a shift to blue color, suggesting that the tryptophan moved into the hydrophobic core of the membrane and could strongly interact with the prokaryotic membrane (Fig. 5a, Table 3).

The water-soluble fluorescent KI quencher was used to determine the degree of A20L interaction with prokaryotic and eukaryotic membranes as it is able to reduce the tryptophan fluorescence in the solution (Fig. 5b). The Ksv value of A20L was lower when added to PC/PG and PC/ Chol liposomes, suggesting that the antimicrobial peptide A20L is deeper inserted into the prokaryotic membrane, and, consequently, exhibit stronger interaction specificity
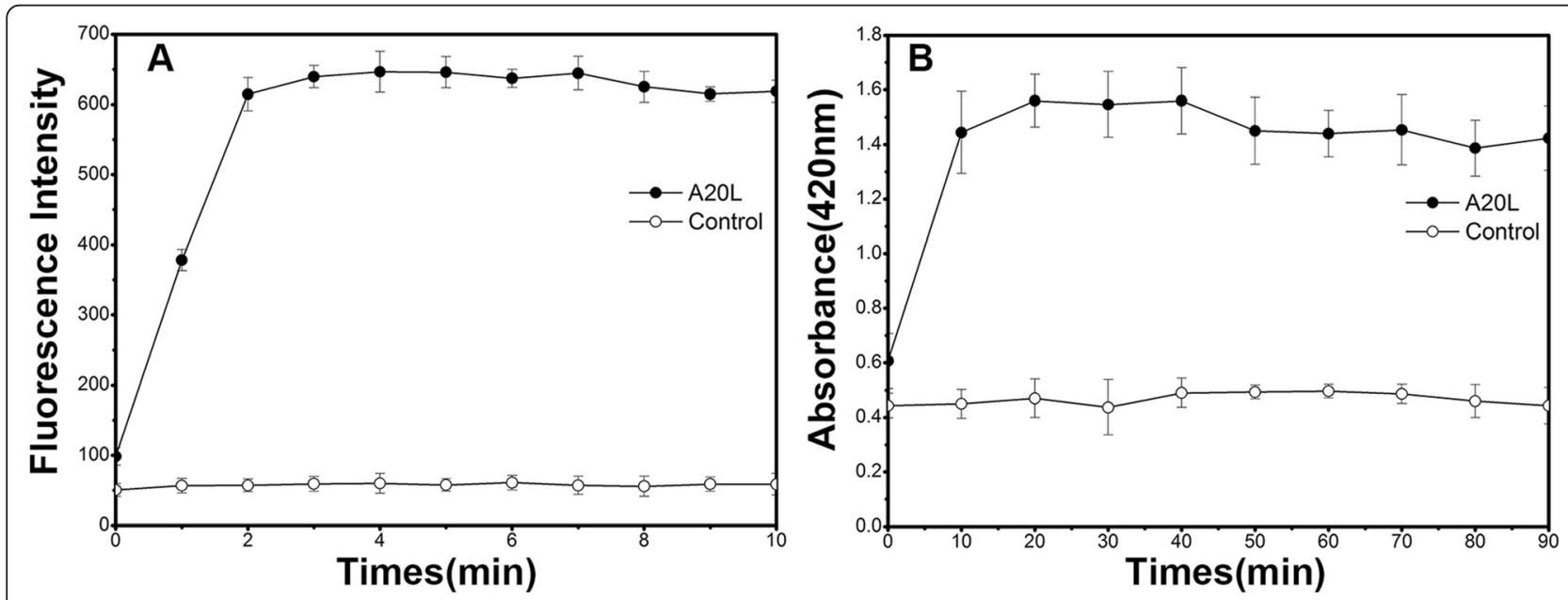

Fig. 4 Membrane permeabilization assay of the antimicrobial peptide A20L. (a) outer membrane permeabilization induced by A20L was detected by NPN uptake in P. aeruginosa ATCC 27853; (b) the effect of A20L on the inner membrane of E. coli ML-35. Release of cytoplasmic $\beta$-galactosidase activity (measured from the $\mathrm{OD}_{420 \mathrm{~nm}}$ ) from E. coli ML-35 treated with A2OL 

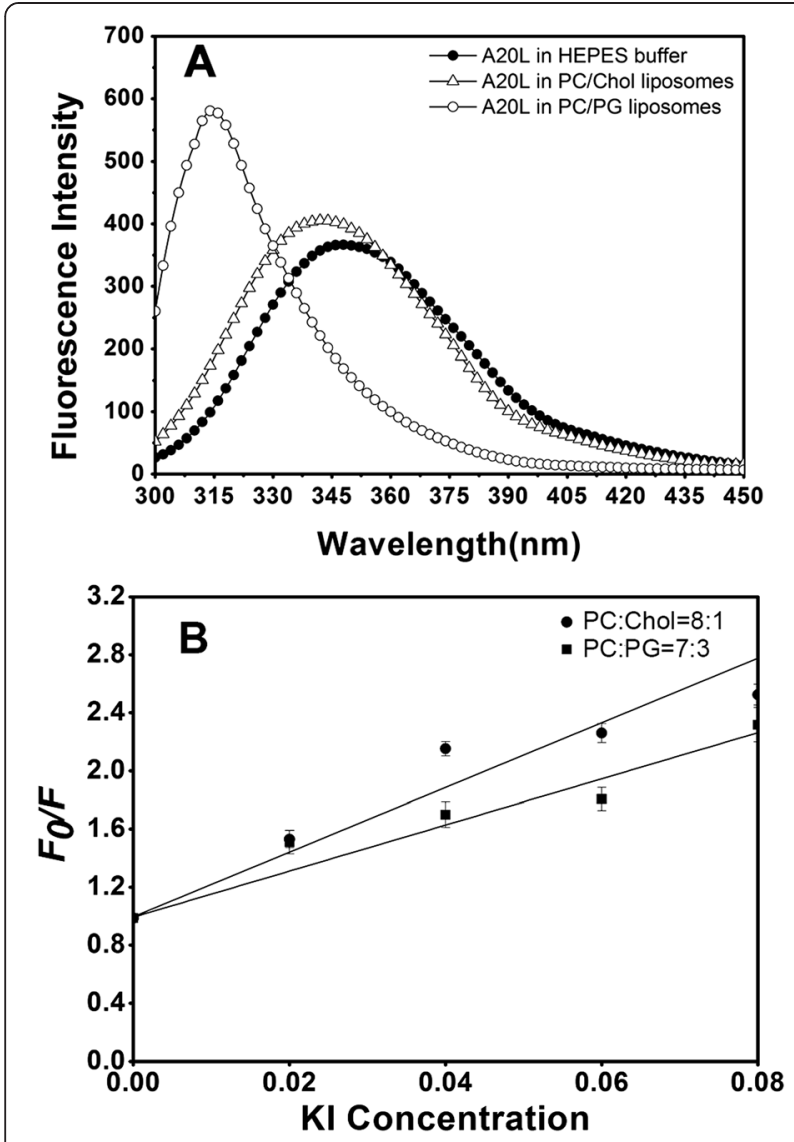

Fig. 5 Fluorescence emission spectra and Stern-Volmer plot of A20L using various liposome models. (a) tryptophan fluorescence emission spectra of the antimicrobial peptide A20L; (b) Stern-Volmer plots of the tryptophan fluorescence were obtained by the sequential addition of the fluorescence quencher $\mathrm{Kl}$

with the prokaryotic membrane than with the eukaryotic one. These results are consistent with the findings from $\mathrm{MIC}, \mathrm{MHC}$ and therapeutic index.

\section{Discussion}

Through the use of fusion tags, the toxicity of AMPs to the host cells can be reduced and their resistance to intracellular protease degradation increased, thereby improving their production yield $[9,12]$. Fusion tags can be classified into aggregation-promoting carriers and solubility-enhancing carriers. The PurF fragment, PaP3.30 and KSI are aggregation-promoting carriers. AMP fused with aggregation-promoting carriers was shown to be toxic

Table 3 Tryptophan fluorescence emission maxima of A20L in different liposome models

\begin{tabular}{|c|c|c|c|c|}
\hline Peptide & Liposome model & Wavelength $(\mathrm{nm})$ & Blue shift (nm) & Intensity \\
\hline & HEPES & 346.7 & - & - \\
\hline \multirow[t]{2}{*}{ A20L } & $\mathrm{PC} /$ Chol = 8:1 & 341.3 & 5.4 & 36.855 \\
\hline & $P C / P G=7: 3$ & 315.7 & 31.0 & 220.809 \\
\hline
\end{tabular}

to host bacterial cells $[9,22]$. Thioredoxin $(17 \mathrm{kDa})$ and glutathione-S-transferase $(26 \mathrm{kDa})$ are solubilityenhancing carriers, but their large molecular weight indirectly led to low AMP yields [23-25]. The Ub-tag and SUMO1/2/3/4-tags are small and thus are useful for increasing the proportion of AMPs in fusion proteins, thereby increasing the yield of AMPs. Currently, NZ17074, lacticin $\mathrm{Q}$ and cecropin $\mathrm{AD}$ have been expressed successfully in E. coli, B. subtilis and P. pastoris by fusion to the SUMO-tag [26-28]. However, yeast cells are most commonly reported as the source of SUMOtagged fusion peptides [11], while Ub-tagged and human SUMO-tagged fusion peptides are rarely reported. The use of a SUMO4-tag and Ub-tag for AMP expression has not yet been reported previously. Herein, we explored the expression of A20L tagged with an Ub-tag and SUMO1/2/3/4-tags to optimize the expression approach of AMP production. Our findings indicate that the expression yield was the highest for the Ub-tag fusion, and the SUMO1-tag was superior to the SUMO2/3/4-tags. It was interesting to see that all the human Ub-tag and SUMO1/2/3/4-tags were effective as fusion tags of AMPs; moreover, the Ub-tag not only promoted the soluble expression of the AMP, but also produced a higher yield than the human SUMO1/2/3/4-tags. The enhancement of both solubility and yield of the peptide A20L obatained by using Ub-tag and human SUMO1/2/3/4-tag systems should enhance the large-scale production of AMPs. Future work will approach further research to optimize the fusion tags in order to increase AMPs production.

AMPs can act by inducing membrane injury or intracellular injury [29]. The antibacterial activity of $\alpha$-helical AMPs depends on their helicity, positive charge and hydrophobicity, etc. After interaction with bacterial cell membranes carrying negative charges, the secondary structure of AMPs is induced to become $\alpha$-helical in nature, destroying the membrane integrity, affecting the electrochemical potential and ionic balance of the cell membrane, resulting in leakage of the cell contents, and finally causing bacterial death [29]. A20L peptides contain hydrophobic and positively charged amino acids [13]. Circular dichroism experiments have shown that the secondary structure of A20L adopted an $\alpha$-helical from a random coil structure after the interaction with hydrophobic solvents that mimick the hydrophobic environment of cell membranes. In the bacterial membrane permeabilization experiments, A20L peptide caused rapid damage to the outer membrane of Gram-negative bacteria, allowing NPN to insert into the hydrophobic environment, thereby yielding increased fluorescence. In addition, after the damage to the bacterial inner membrane by A20L, $\beta$-galactosidase was released from the cells and reacted with the substrate, ONPG, suggesting that the bacterial membrane is the target of A20L peptide. 
Bacterial and eukaryotic cells exhibit many differences in the structure and function of their membranes. Prokaryotic cells with a large amount of negative charges are mainly composed of phosphatidylglycerol, cardiolipin, and phosphatidylserine. In contrast, eukaryotic cells have zwitterionic phospholipids, including phosphatidylethanolamine, phosphatidylcholine, cholesterol, and sphingomyelin. Different membrane lipid compositions play a crucial role in the specificity of AMPs [30]. In this regard, we prepared liposomes containing different phospholipids to mimic prokaryotic and eukaryotic membranes. Tryptophan fluorescence and KI quenching experiments showed a stronger interaction between the A20L peptide and the prokaryotic membrane. The mechanisms used to describe the interaction of AMPs with bacterial cell membranes include the "carpet" model, "barrel-stave" model, "toroidal-pore" model and "aggregate channel" model [5]. We suggest that the "membrane discrimination mechanism" could well describe how $\alpha$-helical AMPs interact with cell membranes as well as the specificity of AMPs [16]. The mechanism depends upon the difference in membrane composition between prokaryotic and eukaryotic cells. A20L forms pores/channels in the hydrophobic core of the eukaryotic bilayer by bundles of amphipathic $\alpha$-helices producing an aqueous pore, it caused the hemolysis of human red blood cells; the mechanism of A20L with eukaryotic cells is a "barrel-stave" mechanism. The positive charge residues of A20L interact with the negatively charged phospholipid in prokaryotic cells, A20L kills prokaryotic cells by the "carpet" mechanism.

\section{Conclusions}

In conclusion, both the Ub-tag and SUMO1/2/3/4-tags may be useful for the fusion expression of $\alpha$-helical AMPs on an industrial scale. Ub-tag was proved as the most efficient approach for the expression of $\alpha$-helical antimicrobial peptide A20L. Application of fusion tags for production of AMPs would help to reduce costs and would be widely applicable for use with a variety of AMPs. The MIC and MHC values indicated that the A20L peptide obtained from the fusion expression showed good antibacterial and low hemolytic activities. The results from the interaction of the A20L peptide with liposomes indicated that the membrane discrimination mechanism may be suitable for explaining the mechanism of action of $\alpha$-helical AMPs.

\section{Additional file}

Additional file 1: Table S1. DNA and amino acid sequences of Ub-A2OL and SUMO 1/2/3/4-A20L. Table S2. Primer sequences for the A2OL genes cloned and fused to SUMO and Ub. (PDF $63 \mathrm{~kb}$ )

\section{Abbreviations}

Ub-tag: Ubiquitin-tag; SUMO-tag: Small ubiquitin-related modifier-tag; MHC: Minimal hemolytic concentration; AMP: Antimicrobial peptide; MIC: Minimal inhibitory concentrations; CD: Circular dichroism; PMSF: Phenylmethanesulfonyl fluoride; TFE: 2,2,2-Trifluoroethanol; NPN: 1-N-Phenylnaphthylamine; ONPG: o-Nitrophenyl $\beta$-D-galactopyranoside; TI: Therapeutic index; BCA: Bicinchoninic Acid; PG: L-a-phosphatidyl-dl-glycerol; PC: L-a-phosphatidylcholine; Chol: Cholesterol; Kl: Potassium iodide.

\section{Competing interests}

The authors declare that they have no competing interests.

\section{Authors' contributions}

Conceived and designed the experiments: YC. Performed the experiments: TY, YH, and SS. Wrote the paper: YC. All authors read and approved the final manuscript.

\section{Acknowledgements}

This work was supported by the National Natural Science Foundation of China (No. 81373445, Y. X. C.), the Innovative Team of Peptide Drugs of Jilin Province (No. 20121807, Y. X. C.), the Natural Science Foundation of Jilin Province (No. 20140101042JC, Y. B. H.) and a Basic Scientific Research Grant from Jilin University (Y. X. C. and Y.B.H)

\section{Author details}

${ }^{1}$ Key Laboratory for Molecular Enzymology and Engineering of the Ministry of Education, Jilin University, 2699 Qianjin St., Changchun, Jilin 130012, P. R. China. ${ }^{2}$ National Engineering Laboratory for AIDS Vaccine, Jilin University, Changchun, China. ${ }^{3}$ School of Life Sciences, Jilin University, Changchun, China.

Received: 8 December 2014 Accepted: 24 July 2015

Published online: 05 August 2015

\section{References}

1. Berger RE. Emergence of a new antibiotic resistance mechanism in India, Pakistan, and the UK: a molecular, biological, and epidemiological study editorial comment. J Urol. 2011;185(1):154-4.

2. Kumarasamy KK, Toleman MA, Walsh TR, Bagaria J, Butt F, Balakrishnan R, et al. Emergence of a new antibiotic resistance mechanism in India, Pakistan, and the UK: a molecular, biological, and epidemiological study. Lancet Infect Dis. 2010;10(9):597-602.

3. Prado Montes DeOca E. Antimicrobial peptide elicitors: new hope for the post-antibiotic era. Innate Immun. 2013;19(3):227-41.

4. Hodges RS, Jiang Z, Whitehurst J, Mant CT. Development of antimicrobial peptides as therapeutic agents. Pharmaceut Sci Encyclopedia. 2011;430:1-73.

5. Li YM, Xiang Q, Zhang QH, Huang YD, Su ZJ. Overview on the recent study of antimicrobial peptides: origins, functions, relative mechanisms and application. Peptides. 2012;37(2):207-15.

6. Neetoo $\mathrm{H}$, Ye M, Chen $\mathrm{H}$. Potential antimicrobials to control Listeria monocytogenes in vacuum-packaged cold-smoked salmon pate and fillets. Int J Food Microbiol. 2008:123(3):220-7.

7. Lazarev VN, Govorun VM. Antimicrobial peptides and their use in medicine Appl Biochem Micro. 2010;46(9):803-14.

8. Marr AK, Gooderham WJ, Hancock REW. Antibacterial peptides for therapeutic use: obstacles and realistic outlook. Curr Opin Pharmacol. 2006;6(5):468-72

9. Li YF. Carrier proteins for fusion expression of antimicrobial peptides in Escherichia coli. Biotechnol Appl Biochem. 2009;54:1-9.

10. Jennissen HP. Ubiquitin and the enigma of intracellular protein degradation. Eur J Biochem. 1995:231(1):1-30.

11. Wang ZY, Li HL, Guan W, Ling HL, Wang ZY, Mu TY, et al. Human SUMO fusion systems enhance protein expression and solubility. Protein Expr Purif. 2010;73(2):203-8

12. Bommarius $B$, Jenssen $H$, Elliott $M$, Kindrachuk J, Pasupuleti M, Gieren $H$ et al. Cost-effective expression and purification of antimicrobial and host defense peptides in Escherichia coli. Peptides. 2010:31(11):1957-65.

13. Chen Y, Guarnieri MT, Vasil Al, Vasil ML, Mant CT, Hodges RS. Role of peptide hydrophobicity in the mechanism of action of alpha-helical antimicrobial peptides. Antimicrob Agents Chemother. 2007;51(4):1398-406. 
14. Catanzariti AM, Soboleva TA, Jans DA, Board PG, Baker RT. An efficient system for high-level expression and easy purification of authentic recombinant proteins. Protein Sci. 2004;13(5):1331-9.

15. Tang YL, Shi YH, Zhao W, Hao G, Le GW. Insertion mode of a novel anionic antimicrobial peptide MDpep5 (Val-Glu-Ser-Trp-Val) from Chinese traditional edible larvae of housefly and its effect on surface potential of bacterial membrane. J Pharm Biomed Anal. 2008;48(4):1187-94.

16. Chen Y, Mant CT, Farmer SW, Hancock RE, Vasil ML, Hodges RS. Rational design of alpha-helical antimicrobial peptides with enhanced activities and specificity/therapeutic index. J Biol Chem. 2005;280(13):12316-29.

17. Lee DL, Mant $C$, Hodges RS. A novel method to measure self-association of small amphipathic molecules: temperature profiling in reversed-phase chromatography. J Biol Chem. 2003:278(25):22918-27.

18. Eriksson M, Nielsen PE, Good L. Cell permeabilization and uptake of antisense peptide-peptide nucleic acid (PNA) into Escherichia coli. J Biol Chem. 2002;277(9):7144-7.

19. Lopez-Exposito I, Amigo L, Recio I. Identification of the initial binding sites of alphas2-casein $\mathrm{f}(183-207)$ and effect on bacterial membranes and cell morphology. Biochim Biophys Acta. 2008;1778(10):2444-9.

20. Huang $Y$, He L, Li G, Zhai N, Jiang H, Chen Y. Role of helicity of alpha-helical antimicrobial peptides to improve specificity. Protein Cell. 2014;5(8):631-42.

21. Mayer LD, Hope MJ, Cullis PR. Vesicles of variable sizes produced by a rapid extrusion procedure. Biochim Biophys Acta. 1986;858(1):161-8.

22. Kim HK, Chun DS, Kim JS, Yun CH, Lee JH, Hong SK, et al. Expression of the cationic antimicrobial peptide lactoferricin fused with the anionic peptide in Escherichia coli. Appl Microbiol Biotechnol. 2006;72(2):330-8

23. LaVallie ER, Lu ZJ, Diblasio-Smith EA, Collins-Racie LA, McCoy JM. Thioredoxin as a fusion partner for production of soluble recombinant proteins in Escherichia coli. Methods Enzymol. 2000;326:322-40.

24. Majerle A, Kidric J, Jerala R. Production of stable isotope enriched antimicrobial peptides in Escherichia coli: An application to the production of a N-15-enriched fragment of lactoferrin. J Biomol NMR. 2000;18(2):145-51

25. Li YF. Recombinant production of antimicrobial peptides in Escherichia coli: a review. Protein Expr Purif. 2011;80(2):260-7.

26. Chen X, Zhu F, Cao Y, Qiao S. Novel expression vector for secretion of cecropin $A D$ in Bacillus subtilis with enhanced antimicrobial activity. Antimicrob Agents Chemother. 2009:53(9):3683-9.

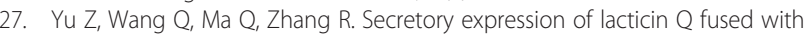
SUMO in Bacillus subtilis. Protein Expr Purif. 2013:89(1):51-5.

28. Wang XJ, Wang XM, Teng D, Zhang Y, Mao RY, Wang JH. Recombinant production of the antimicrobial peptide NZ17074 in Pichia pastoris using SUMO3 as a fusion partner. Lett Appl Microbiol. 2014;59(1):71-8.

29. Brogden KA. Antimicrobial peptides: pore formers or metabolic inhibitors in bacteria? Nat Rev Microbiol. 2005:3(3):238-50.

30. Yeaman MR, Yount NY. Mechanisms of antimicrobial peptide action and resistance. Pharmacol Rev. 2003:55(1):27-55.

\section{Submit your next manuscript to BioMed Central and take full advantage of:}

- Convenient online submission

- Thorough peer review

- No space constraints or color figure charges

- Immediate publication on acceptance

- Inclusion in PubMed, CAS, Scopus and Google Scholar

- Research which is freely available for redistribution 